\title{
Critical factors to be considered when planning the implementation of environmental improvements and energy saving
}

\author{
Juliane Barbosa dos Santos \\ Charbel José Chiappetta Jabbour \\ UNESP - Sao Paulo State University, Brazil
}

\begin{abstract}
To identify the critical success factors in the adoption of energy efficiency actions in Brazilian hospitals and describe their behaviour are the objectives of this paper. In order to achieve these goals, a literature review was performed on green management and energy efficiency. This was the basis to define the questions of the interview script applied to two hospitals located in the state of São Paulo, Brazil. The interview script application was complemented by secondary data and direct observation. The results showed that: a) the studied hospitals are embracing environmental management actions more often and, whenever possible, energy efficiency actions are taken as well; and b) in the cases analysed top management support, commitment with the environment, green process design and employee empowerment were some of the most relevant critical success factors to the accomplishment of energy efficiency actions. These findings may be of interest to emerging countries, including BRICS (Brazil, Russia, India, China and South Africa).

Keywords: Brazil; energy efficiency; critical success factors; sustainability; green management; hospitals
\end{abstract}

\section{Introduction}

An essential green management strategy, energy efficiency has been suggested as a road towards sustainable development, which is in turn, considers the best way to harmonize the economy, the environment and the society of today and tomorrow (Wu et al., 2012). Nevertheless, the majority of studies (Rohdin, 2007; Sardianou, 2008; Van Berkel, 2007; Walsh and Thornley, 2012) on energy efficiency discuss the reality of the developed countries and of the manufacturing sector (Taghizadeh and Pourrabbi, 2013; Fleiter et al.,
2011; Garcia, et al., 2007). Thus, there is a literature gap, that is, a lack of research on developing countries - such as Brazil - on service sectors - such as hospitals - in the energy efficiency state-of-theart body of knowledge.

Therefore, the analytical focus of this paper is on energy efficiency in Brazilian hospitals, due to the energy-saving opportunities found on the premises (heating, hot water, lighting and other related consumptions) and due to the fact that hospitals are supposed to provide patients with top comfortable facilities, by means of modern technology or management strategies which will assure power cost reduction (Congradac et al., 2012).

After the literature review of satisfactory experiences from energy efficiency practices in hospitals (Santamouris et al., 1994; Szklo et al., 2004; Bizzarri and Morini, 2006; Bujak, 2010; Saidur et al., 2010; Sanz-Calcedo et al., 2011; Vanhoudt et al., 2011; Congradac et al., 2012; Çakir et al., 2012), it was verified that the Brazilian scenario Latin America's most economically significant country and BRIC member - is not properly assessed.

Based on existing gaps, the objective of this study is to identify the critical success factors in the adoption of green management and energy efficiency actions in Brazilian hospitals. Because this research topic is still exploratory, it is qualitative research, using a two-case study strategy in order to achieve its proposed goal.

\section{Conceptual background \\ 2.1 Green management and energy efficiency in Brazil}

Green management can be defined as an organizational process outlined to reach environmental sustainability, reduce waste, obtain corporate social responsibility and competitive advantage by fostering green goals and strategies totally integrated with 
the company's objectives and strategies (Jabbour et al., 2012).

Many green management studies are focused on industrial organizations, because their activities have a greater visible environmental impact. The service companies - known as the 'silent destroyers of the environment' - are given much less attention (Molina-Azorín et al., 2009).

However, even service companies can adopt three types of green management practices (González-Benito and González-Benito, 2006):

- Organizational and planning practices, related with the Environmental Management

- System (EMS) development and implementation, as well as other organizational aspects which are important to the environmental management;

- Communication practices, related with the communication on developed environmental actions; and

- Operational practices, related with the operational changes performed in the production system and in the operations, which are important to the environmental issues.

Pursuant to the World Business Council for Sustainable Development (WBCSD) (2012), the principle of eco-efficiency, which is related with operational environmental practices (GonzálezBenito and González-Benito, 2006) - is achieved by delivering goods and services at competitive prices, meeting the human needs and providing quality of life, while progressively diminishing the ecological impacts and the resource intensity along its life cycle, creating more value and reducing the impact.

The eco-efficiency has three main dimensions (WBCSD, 2012):

- Reduction of the resource consumption: includes the minimization of the use of energy, materials, water and earth; recycling increase and product durability;

- Reduction of the impact on the environment: includes the minimization of air emissions, water discharges, waste elimination and dispersion of toxic substances, as well as the promotion of the sustainable use of renewable resources;

- Enhancement of product/service value, meaning the offer of greater benefits to clients by the functionality, flexibility and modularity of the product, enabling the achievement of the same functional need by the client with less materials and resources.

Some organizations have a fourth dimension: the EMS implementation (WBCSD, 2012). There are many eco-efficiency actions, such as the reduction in the consumption of water or energy (Van Berkel, 2007). Energy efficiency is a powerful and cost-effective way to supply the sustainable development requirements against the dependence on fossil fuels (Al-Mansour, 2011). In Brazil, the energy efficiency activities started in 1984 with the establishment of Inmetro (National Institute of Metrology, Quality and Technology), currently responsible for the Brazilian Labelling Program on Energy Efficiency (Bodach and Hamhaber, 2010). In 1985, the Brazilian National Program of Electric Energy Conservation (PROCEL) was devised in order to promote the conservation of electric energy according to the supply and demand, so that the investment costs in the electricity generation sector could be curtailed (Bodach and Hamhaber, 2010).

After the 2001 energy crisis, the National Policy for Conservation and Rational Use of Energy, Law No. 10.295, from October 17, 2001 was established, with a focus on elaborating the consumption limits or the minimum requirements to the energy efficiency of power-consuming machines or devices (Bodach and Hamhaber, 2010). On December 11, 2002 the 4.508 decree was set up, becoming a further step in the voluntary process of energy efficiency improvement (Garcia et al., 2007).

The 'Procel Edifica' action plan was approved in September 2006. It performs the voluntary labelling of the energy efficiency levels in public, commercial and service buildings (Carlo and Lamberts, 2008). The Brazilian Energy Plan estimates to 2030 that the energy efficiency actions in the electric sector may avoid the consumption of 53 TWh of energy (Sheinbaum et al., 2011).

\subsection{Critical success factors of energy efficiency in hospitals}

The Critical Success Factors (CSF) are intended to clarify the important areas that influence the organizational success (Eni, 1989), especially useful to the performance management and organizational excellence measurement (Xu et al., 2011).

The literature review on green management critical success factors (Daily and Huang, 2001; Babakri et al., 2003; Zutshi and Sohal, 2004; Chavan, 2005; Wee and Quazi, 2005; Zutshi et al., 2008; Sambasivan and Fei, 2008) enabled the identification of the factors shown in Table 1.

Hospitals are major power consumers, since they are supposed to provide patients with top comfortable facilities and may save a great deal of energy efficiency (Congradac et al., 2012).

Hospitals as central health care providers can minimize the negative side effects from their activities to the environment by applying the sustainability concept in green building projects, energy efficiency improvement or environmental management systems (Weisz et al., 2011).

\subsection{Conceptual framework of the study}

A conceptual framework was set up to relate the most relevant concepts from this research, thus proposing a mutual relationship, for posterior verification that such framework is adherent or not to the 
Table 1: Systematization of the critical success factors related with green management

\begin{tabular}{|c|c|c|}
\hline $\begin{array}{l}\text { Environmental } \\
\text { management CSF }\end{array}$ & Concepts & Research \\
\hline $\begin{array}{l}\text { Top management } \\
\text { support }\end{array}$ & $\begin{array}{l}\text { Communication of the policy, plan and further worker-related } \\
\text { information; } \\
\text { Leadership, management and support; } \\
\text { Reluctance in providing the needed resources; } \\
\text { Top management commitment; } \\
\text { Provision of basic training. }\end{array}$ & $\begin{array}{l}\text { Daily and Huang (2001); } \\
\text { Zutshi and Sohal (2004); } \\
\text { Chavan (2005); Wee and } \\
\text { Quazi (2005); Zutshi et al. } \\
\text { (2008); Sambasivan and } \\
\text { Fei (2008) }\end{array}$ \\
\hline $\begin{array}{l}\text { Commitment with } \\
\text { the environment }\end{array}$ & $\begin{array}{l}\text { Increasing pressure from clients, government and other parties } \\
\text { interested in demonstrating environmental commitment. }\end{array}$ & Sambasivan and Fei (2008) \\
\hline Green process design & Procedures and activities in the green process factor area. & Wee and Quazi (2005) \\
\hline $\begin{array}{l}\text { Employee } \\
\text { empowerment }\end{array}$ & $\begin{array}{l}\text { The skilled employees have autonomy and decision power, } \\
\text { being more inclined to get involved in the environmental } \\
\text { improvement; } \\
\text { The responsibility increase may cause the employees to } \\
\text { oppose the EMS. }\end{array}$ & $\begin{array}{l}\text { Daily and Huang (2001); } \\
\text { Chavan (2005) }\end{array}$ \\
\hline EMS & $\begin{array}{l}\text { Time, effort and high EMS implementation cost; } \\
\text { The EMS integration may allow the organizations for being } \\
\text { more competitive in business; } \\
\text { Long-term initiatives in the EMS adoption. }\end{array}$ & $\begin{array}{l}\text { Babakri et al. (2003); } \\
\text { Zutshi and Sohal (2004); } \\
\text { Zutshi et al. (2008) }\end{array}$ \\
\hline $\begin{array}{l}\text { Supplier } \\
\text { management }\end{array}$ & $\begin{array}{l}\text { All involved parties in the environmental management } \\
\text { - enclosing suppliers, clients and employees. }\end{array}$ & Wee and Quazi (2005) \\
\hline $\begin{array}{l}\text { Information } \\
\text { management }\end{array}$ & $\begin{array}{l}\text { Information share among the organizations may help in } \\
\text { finding solutions. }\end{array}$ & Wee and Quazi (2005) \\
\hline $\begin{array}{l}\text { Advanced environ- } \\
\text { mental management } \\
\text { practices }\end{array}$ & $\begin{array}{l}\text { Life Cycle Analysis (LCA); } \\
\text { Design for Disassembly (DFD); } \\
\text { Industrial ecology. }\end{array}$ & Zutshi and Sohal (2004) \\
\hline Rewards & $\begin{array}{l}\text { Reinforce the empowerment and the decision-making process; } \\
\text { Motivation to continue with the good environmental practices.; }\end{array}$ & Daily and Huang (2001) \\
\hline Review and & $\begin{array}{l}\text { Belief that there is no need for constant review and } \\
\text { improvement; }\end{array}$ & Chavan (2005); \\
\hline improvement & To a continuous, adequate and effective management. & Sambasivan and Fei (2008); \\
\hline Teamwork & $\begin{array}{l}\text { The contribution of each individual to the organizational well- } \\
\text { being is important to an accomplished EMS; } \\
\text { Creation of green teams to implement the environmental projects; } \\
\text { Organizations committed with the environment are inclined to } \\
\text { reinforce teamwork and loyalty. }\end{array}$ & $\begin{array}{l}\text { Daily and Huang (2001); } \\
\text { Wee and Quazi (2005); } \\
\text { Sambasivan and Fei (2008) }\end{array}$ \\
\hline $\begin{array}{l}\text { Environmental } \\
\text { training }\end{array}$ & $\begin{array}{l}\text { Preparation of employees to new environmental operations, } \\
\text { helping in corrective action efforts; } \\
\text { The employees need to be aware of the importance of their } \\
\text { operations to the organization and the environmental impact; } \\
\text { The training length may originate various outcomes. }\end{array}$ & $\begin{array}{l}\text { Daily and Huang (2001); } \\
\text { Zutshi and Sohal (2004); } \\
\text { Zutshi et al. (2008) }\end{array}$ \\
\hline
\end{tabular}

analysed cases (Figure 1). The green practices proposed by González-Benito and González-Benito (2006) with the energy efficiency and its dimensions allocated into the operational practices are presented in this framework. The research focus is on energy efficiency in hospitals, trying to discover which most relevant critical success factors facing the constant demands from the reduction of the energy consumption (Szklo et al., 2004).

\section{Research methodology}

This study is devoted to understand the energy efficiency CSF in Brazilian hospitals. According to a search made from the ISI Web of Science and Scopus, studies with this analytical focus were not located during 2011 and 2012 (using the keywords of this paper). This way, the topic can be regarded as exploratory. In this context, qualitative research is the most appropriate one, with an option for the case study strategy (two cases) (Voss et al., 2002).

The data to this research comes from two hospitals in the state of São Paulo, Brazil. After the agreement, interview date and time, direct observation and document analysis for data was established. This phase took place in 2012, in Hospitals 1 and 2 , according to Table 2.

\section{Results}

Hospital 1 refers to a large Philanthropic hospital, with about 230 beds. Hospital 1 presents the fol- 


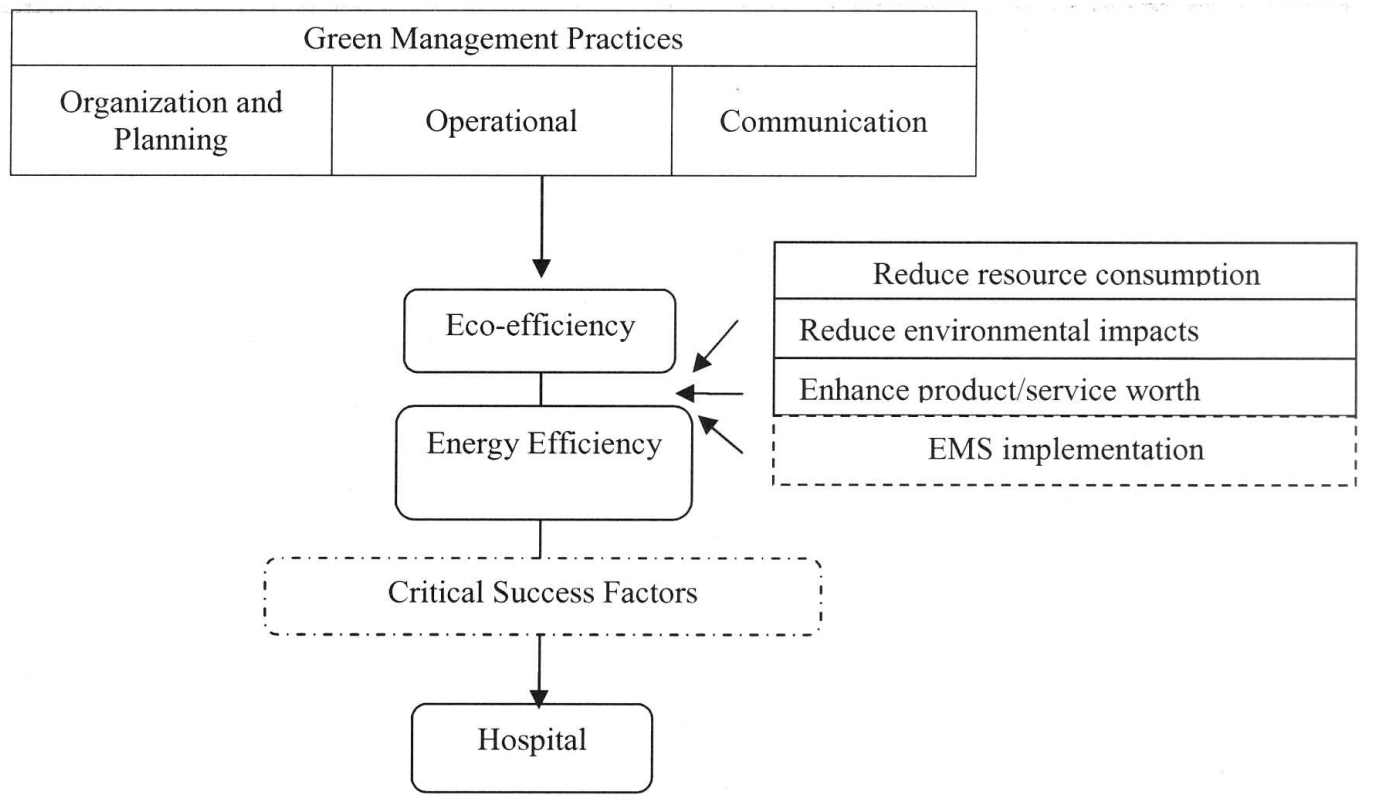

Figure 1: Framework with the green management critical success factors focusing on energy eco-efficiency

Table 2: Data collection procedures summary

\begin{tabular}{llcl}
\hline \multicolumn{4}{c}{ Data collection dynamics } \\
\hline Hospital & Type & Interviewee & Documents \\
\hline 1. & General Hospital / & Infrastructure and Project Manager & $\begin{array}{l}\text { Documents available in the Unit website. } \\
\text { Documents on the Unit history and data. }\end{array}$ \\
\hline 2 & Specialized Hospital / & Maintenance Engineer & $\begin{array}{l}\text { Documents available in the Unit website. } \\
\text { ocuments on the Unit history and data. }\end{array}$ \\
\hline
\end{tabular}

lowing green practices: Healthcare Waste Management Plan, a campaign against disposable cups, campaign for imaging examination material collection, own water collection and storage system, substitution of bulbs and air-conditioning device use control.

Hospital 2 refers to a medium-sized public hospital. It has 91 beds. Hospital 2 presents the following green practices: Healthcare Waste Management Plan, Water Conservation Program, proper battery and bulb disposal, substitution of bulbs, correct use of the air-conditioning device, Plan for the Rational Use of Energy and an implementing project on individual energy control.

Hospitals 1 and 2 present similarities in the critical success factors regarding green management. These similarities can be observed based on each CSF adopted by this research and described further.

\subsection{Top management support}

To Daily and Huang (2001), Zutshi and Sohal (2004), Chavan (2005), Wee and Quazi (2005), Zutshi et al., (2008) and Sambasivan and Fei (2008), an environmentally aware top management enables an open and participative employee management. Both hospitals have top management support as a critical success factor. According to the interviewee from Hospital 1, there is both support and pressure for green issues. In Hospital 2, such a critical factor is highlighted by the support for green trainings and release of budgetary resources.

\subsection{Commitment to the environment}

The commitment with the green responsibilities is listed by Sambasivan e Fei (2008) as a critical success factor. In both studied hospitals, one can find support and incentive in the sustainability-related issues as well as pressures originated from the surrounding community.

\subsection{Green process design}

Wee and Quazi (2005) developed and validated a set of green management critical success factors based on bibliographic research and interviews with environmental managers, thus establishing the green process design as a core critical factor.

The green process design critical factor corresponds in Hospital 1 to the Healthcare Waste Management Plan, campaign against disposable cups, campaign for imaging examination material collection, own water collection and storage system, substitution of bulbs and air-conditioning device use control.

In Hospital 2, the green process design critical 
factor corresponds to the Healthcare Waste Management Plan, Water Conservation Program, proper battery and bulb disposal, substitution of bulbs, correct use of the air-conditioning device, Plan for the Rational Use of Energy and an implementing project on individual energy control.

\subsection{Employee empowerment}

To Daily and Huang (2001), motivated and engaged employees are more participative when involved in advanced green management practices. The employee empowerment can be realized in Hospital 1 due to the fact that the interviewee infrastructure and project manager - has proposed and led green management-related ideas, such as the feasibility study on the replacement of fluorescent bulbs with LED bulbs. In the second case, the interviewee - a maintenance engineer - has autonomy to accomplish a feasibility study, such as to study energy sectorial sub-metering, so that expenses can be better controlled.

\subsection{Environmental management systems}

The critical factor related to Environmental Management System (EMS) implementation is important to Babakri et al., (2003), Zutshi and Sohal (2004) and Zutshi et al., (2008), because they enable corporate competitiveness. Both hospitals lack the EMS, and to date there is no intention recorded to implement it.

\subsection{Supplier management}

The supplier management critical success factor is inclusive of clients, suppliers and employees, and all must be involved in the green management, a relevant item to Wee and Quazi (2005). The supplier management critical success factor in the green management area was not found in both hospitals.

\subsection{Information management}

According to Wee and Quazi (2005), the share of information among organizations can lead to solutions. At first, the share of information among organizations in order to solve problems was not detected in both cases. Information shared via the web in the first case and internally in the second case solely informs the public on projects or news already consolidated.

\subsection{Adoption of advanced green management practices}

The adoption of green management practices are inserted in major critical success factor categories presented by Zutshi and Sohal (2004), and they can be used in any organization, regardless of its size, business nature or sector. On advanced green management practices focusing on energy efficiency, it is highlighted in the second case the Plan for the Rational Use of Energy. The substitution of bulbs and the correct use of the air conditioning device are the directed practices, among others. In the first case, the energy efficiency measurements are limited to substitution of bulbs and the use of the air conditioning device only in areas of great need.

\subsection{Employees rewards}

A reinforcement to continuously motivate the commitment of the employees with the green issues is an important factor to Daily and Huang (2001). The reward critical success factor was not attested with factors related with the environmental issues in none of the cases studied. Thus, there are no bonuses for energy saving in the studied hospitals.

\subsection{Review and improvement}

According to Chavan (2005) constant reviews and improvement are needed in order to have a continuous, adequate and effective management (Sambasivan and Fei, 2008). The review and improvement critical success factor was not identified in the first case, but it can be observed in the second case, when the interviewee states that in the 2002 energy crisis ('the 2002 Brazilian blackout'), the employees revised the energy saving related project, and a new awareness arose.

\subsection{Teamwork}

The contribution of each individual, combining competences in the organization is important to a successful green management (Daily and Huang, 2001). In the first case, the teamwork critical success factor is related with several actions, among them the total employee adherence to the disposable cup campaign, as well to the non-use of air conditioning devices in unnecessary areas and also to trivial actions such as turning off the light when leaving a place. According to Wee and Quazi's conception (2005), the creation of green teams is needed to the implementation of the environmental projects. In the second case, the main difficulty is maintaining the employee awareness; as time goes by such awareness undergoes a common relaxation. The employee awareness is the main obstacle in the adoption of green practices.

\subsection{Environmental training}

The environmental training prepares the employees to new green operations and helps in the corrective action efforts (Daily and Huang, 2001). In the first case, there is no specific environmental training but a general week training performed to the new employees, in which some orientations are transmitted, among them the environmental-related ones. In the second case, when the eco-efficiency programs were installed, there was training in mid1997. As the employees need to be aware of their organizational operations and their environmental impact (Zutshi and Sohal, 2004), a new training 
was again reinforced during the energy crisis, known as the '2002 Brazilian blackout'.

\section{Discussing the adherence between the proposed framework and reality of Hospitals 1 and 2 cases}

In Figure 2, an empirical framework refining the conceptual framework (Figure 1) was presented to relate the environmental management critical success factors with a focus on the energy efficiency. From the four dimensions based on the WBCSD (2012), both hospitals have three of them (reduction in the resource consumption, reduction of the nature impact and enhancement of the service value). The fourth dimension constituted by the implementation of an EMS does not take place in the two hospital units. Also there is no intention to date to implement the EMS.

In both cases, the 'reduction of the resource consumption' is the central issue. Searching for further green actions, both hospitals attempt to accomplish projects aiming at saving energy, basically. The energy efficient practices seemed to be related with one another:

- To Hospital 1, one can highlight the employee empowerment, commitment with the environment, green management practices, green process design, top management support, teamwork and environmental training;

- To Hospital 2, it is highlighted the employee empowerment, commitment with the environment, green management practices, green process design, top management support, teamwork, environmental training and review and improvement;

- In an exploratory way, it was possible in addition to spot critical factors not yet met, that is, barriers that should be overcome, both for Hospital 1 (financial and lack of sub-metering) and for Hospital 2 (human organizational factors and lack of sub-metering).

This way the conceptual framework is adequate to offer understanding on energy efficiency CSF in Hospitals 1 and 2, also suggesting that the topic 'barriers to energy efficiency' should be incorporated to the empirical framework, refining the conceptual framework. Further, the EMS is lacking in reality.

\section{Conclusion}

The aim of this study is to identify the critical success factors in the adoption of energy eco-efficiency programs in some Brazilian hospitals. In order to achieve this goal, a literature review on the topic was held and a case study was conducted using evidence from two hospitals located in the state of São Paulo, Brazil. The two cases were analysed regarding a brief hospital characterization, green manage- ment characterization and finally the energy efficiency and CSF characterization.

In Hospital 1, the critical success factors are the top management support, the commitment with the environment, green process design, employee empowerment, advanced environmental management practices, environmental training and teamwork.

In Hospital 2, the critical success factors are top management support, commitment with the environment, green process design, employee empowerment, advanced environmental management practices, review and improvement, environmental training and teamwork.

Table 3 shows the two studied cases relating the critical success factors and the main barriers found. Therefore, the objective proposed by this study was achieved.

\section{Table 3: Systematization of the opportunities and barriers found in the studied cases}

\begin{tabular}{|c|c|}
\hline \multicolumn{2}{|c|}{ Critical success factors } \\
\hline Hospital 1 & Hospital 2 \\
\hline top management support; & top management support; \\
\hline $\begin{array}{l}\text { commitment with the } \\
\text { environment; }\end{array}$ & $\begin{array}{l}\text { commitment with the } \\
\text { environment; }\end{array}$ \\
\hline green process design; & green process design; \\
\hline employee empowerment; & employee empowerment; \\
\hline $\begin{array}{l}\text { advanced environmental } \\
\text { management practices; }\end{array}$ & $\begin{array}{l}\text { advanced environmental } \\
\text { management practices; }\end{array}$ \\
\hline environmental training; & review and improvement; \\
\hline \multirow[t]{2}{*}{ teamwork. } & environmental training; \\
\hline & teamwork. \\
\hline
\end{tabular}

According to this context, this study shares its contribution with two cases in hospitals from the state of São Paulo. As a suggestion, a future study should analyse the support from specialized consultancy on energy efficiency to Hospitals' sustainability, exploring critical barriers and factors of success

\section{References}

Al-Mansour F. (2011). 'Energy efficiency trends and policy in Slovenia', Energy, Vol. 36, pp.1868-1877.

Babakri, K.A, Bennett R.A, and Franchetti M. (2003). 'Critical factors for implementing ISO 14001 standard in united states industrial companies', Journal of Cleaner Production, vol. 11, pp.749-752.

Bizzarri G., and Morini G. L. (2006). 'New technologies for an effective energy retrofit of hospitals', Applied Thermal Engineering, Vol. 26, pp.161-169.

Bodach S, and Hamhaber J. (2010). 'Energy efficiency in social housing: Opportunities and barriers from a case study in Brazil', Energy Policy, Vol. 12, pp. 7898-7910. 
Bujak J. (2010). 'Heat consumption for preparing domestic hot water in hospitals', Energy and Building, Vol. 42, pp. 1047-1055.

Çakir U, Çomakli K., and Yuksel F. (2012). 'The role of cogeneration systems in sustainability of energy', Energy Conversion and Management, (in press).

Carlo J., and Lamberts R. (2008). 'Development of envelope efficiency labels for commercial buildings: Effect of different variables on electricity consumption', Energy and Buildings, vol.40, pp. 2002-2008.

Chavan M. (2005). 'An appraisal of environment management systems: A competitive advantage for small businesses', Management of Environmental Quality: An International Journal, Vol. 16, pp. 444-463.

Congradac V, Prebiracevic B, Jorgovanovic N, and Stanisic D (2012). 'Assessing the energy consumption for heating and cooling in hospitals', Energy and Buildings, Vol. 48, pp. 146-154.

Daily B.F, and Huang S. (2001). 'Achieving sustainability through attention to human resource factors in environmental management', International Journal of Operations \& Production Management, vol. 21, pp. 1539-1552.

Eni G.O. (1989). 'The concept of critical success factors (CSFs) as a planning tool for healthcare managers', Health Management Forum, Vol.2, pp. 12-17.

Fleiter T, Worrell E., and Eichhammer W. (2011). 'Barriers to energy efficiency in industrial bottom-up energy demand models - a review', Renewable and Sustainable Energy Reviews, Vol. 6, pp. 3099-3111.

Garcia A.G.P, Szklo A.S, Schaeffer R., and Mcneil M A. (2007). 'Energy-efficiency standards for electric motors in Brazilian industry', Energy Policy, Vol. 35, pp. 3424-3439.

González-Benito J, and González-Benito O. (2006). 'A review of determinant factors of environmental proactivity', Business Strategy and the Environment, Vol.15, pp. 87-102.

Jabbour C.J.C., Silva E.M, Paiva E.L., and Santos F.C.A. (2012) 'Environmental management in Brazil: is it a completely competitive priority?' Journal of Cleaner Production, Vol. 21, pp. 11-22.

Molina-Azorín J.F, Claver-Cortés E, Pereira-Moliner J., and Tarí J.J. (2009). 'Environmental practices and firm performance: an empirical analysis in the Spanish hotel industry', Journal of Cleaner Production, Vol.17, pp. 516-524.

Rohdin P, Thollander P, and Solding P. (2007). 'Barriers to and drivers for energy efficiency in the Swedish foundry industry', Energy Policy, Vol. 35, pp. 672677.

Saidur R, Hasanuzzaman M, Yogeswaran S, Mohammed H A, and Hossain M S. (2010). 'An end-use energy analysis in a Malaysian public hospital', Energy, Vol. 35, pp. 4780-4785.

Sambasivan M. and Fei N.Y. (2008). 'Evaluation of critical success factors of implementation of ISO 14001 using analytic hierarchy process (AHP): a case study from Malaysia', Journal of Cleaner Production, Vol.16, pp.1424-1433.

Sardianou E. (2008). 'Barriers to industrial energy efficiency investments in Greece', Journal of Cleaner Production, Vol. 16, pp.1416-1423.
Santamouris M., Dascalaki E, Balaras C, Argiriou A., and Gaglia A. (1994) 'Energy performance and energy conservation in health care buildings in Hellas', Energy Conversion Management, vol.35, pp. 293-305.

Sanz-Calcedo J G, Blázquez F C, Rodríguez F.L, RuizCelma A. (2011). 'Influence of the number of users on the energy efficiency of health centres', Energy and Buildings, Vol. 43, pp. 1544-1548.

Sheinbaum C, Ruíz B.J, and Ozawa L. (2011). 'Energy consumption and related $\mathrm{CO}_{2}$ emissions in five Latin American countries: Changes from 1990 to 2006 and perspectives', Energy, Vol.36, pp. 3629-3638.

Szklo A S, Soares J.B, and Tolmasquim M.T. (2004). 'Energy consumption indicators and CHP technical potential in the Brazilian hospital sector', Energy Conversion and Management, Vol. 45, pp. 20752091.

Taghizadeh, H., and Pourrabbi, M.V. (2013). 'Energy cost versus production as a performance benchmark for analysis of companies', Journal of Energy in Southern Africa, Vol.24, pp. 2-8.

Voss, C, Tsikriktsis, N, and Frohlich, M. (2002). 'Case research in operations management', International Journal of Operations \& Production Management, Vol. 2, pp.195-219.

Vanhoudt D, Desmedt J, Van Bael J, Robeyn N, and Hoes H. (2011). 'An aquifer thermal storage system in a Belgian hospital: Long-term experimental evaluation of energy and cost savings', Energy and Buildings, Vol. 43, pp. 3657-3665.

Van Berkel R. (2007). 'Eco-efficiency in primary metals production: Context, perspectives and methods', Resources, Conservation and Recycling, Vol. 51, pp.511-540.

Walsh C, and Thornley P. (2012). 'Barriers to improving energy efficiency within the process industries with a focus on low grade heat utilization', Journal of Cleaner Production, Vol. 23, pp. 138-146.

World Business Council for Sustainable Development WBCSD. (2012). 'Corporate social responsibility: making good business sense', WBCSD, 2000. Available at: http://www. wbcsd. Org, Access: May 2012.

Wee Y S, and Quazi H A. (2005). 'Development and validation of critical factors of environmental management', Industrial Management \& Data Systems, Vol.105, pp. 96-114.

Weisz U, Hass W, Pelikan J M, and Schmied H. (2011). 'Sustainable hospitals: A socio-ecological approach', Gaia, Vol.20, pp. 191-198.

Wu J, Wu Z, and Holländer R. (2012). 'The application of Positive Matrix Factorization (PMF) to eco-efficiency analysis', Journal of Environmental Management, Vol.98, pp. 11-14.

Xu P., Chan E.W, and Qian Q.K. (2011). 'Success factors of energy performance contracting (EPC) for sustainable building energy efficiency retrofit (BEER) of hotel buildings in China', Energy Policy, Vol.39, pp. 7389-7398.

Zutshi A., and Sohal A S. (2004). 'Adoption and maintenance of environmental management systems: Critical success factors', Management of 
Environmental Quality: An International Journal, Vol.15, pp. 399-419.

Zutshi A., Sohal A.S, and Adams C. (2008).

'Environmental management system adoption by government departments/agencies', International Journal of Public Sector Management, Vol. 21, pp. 525-539.

Received 23 February 2013; revised 22 November 2013 